$P-8$

\title{
認定痛風医を頼りに紹介受診され, コルヒチンカバーが有効であった痛風患者の一症例
}

\author{
大坪 俊夫
}

\begin{abstract}
症例
58 歳男性.

健診にて 40 歳代より高尿酸血症を指摘されて いた５1歳時，右足第二指のMP関節部に一致し て激しい痛みを認め近医受診。痛風と診断され, NSAIDs内服により発作は軽快した。その後, 毎 年の健診で高尿酸血症を指摘されていたが放置し ていた，昨年 4 月，左足 第三指の MP 関節部の 発赤, 痛みを認め近医整形外科受診. 血清尿酸值 $8.7 \mathrm{mg} / \mathrm{dl}$ と高值を認め痛風の診断でNSAIDs 内服 開始し痛みは一旦改善した。発作出現約 2 週間後 よりトピロキソスタット $40 \mathrm{mg} /$ 日内服開始となっ たが，左足第三指のMP関節部に前回よりも激し い痛みが出現. NSAIDs内服するも今度は右足第 二指 MP 関節に痛みが出現し，その後第三指や第 一指などに痛みが移動した。約 2 か月間 NSAIDs の内服を継続するも痛みが治まらないため, イン
\end{abstract}

ターネット検索で見つけたコルヒチンカバーの治 療方法を主治医に相談。8月の始めより NSAIDs に加え毎日コルヒチン 1 錠 $(0.5 \mathrm{mg})$ の内服開始, 7 日目くらいより痛みは改善, 47 日間内服を継続. コルヒチン中止後 5 日目より痛みが再燃. コルヒ チン再開始で痛みは軽快. インターネット検索で 見つけた認定痛風医による今後の治療を希望され 主治医相談. 当科紹介受診となった.

\section{考察}

今回, 認定痛風医を頼りに紹介受診された症例 を始めて経験した。インターネットを利用し，患 者さん自身が治療方法を調べて積極的に医師に相 談. 認定痛風医に関しても，インターネットで検 索され，当科を紹介受診された。認定痛風医とし て, 無症候性高尿酸血症並びに痛風の生活指導と 治療に関するより深い知識の必要性を強く感じた.

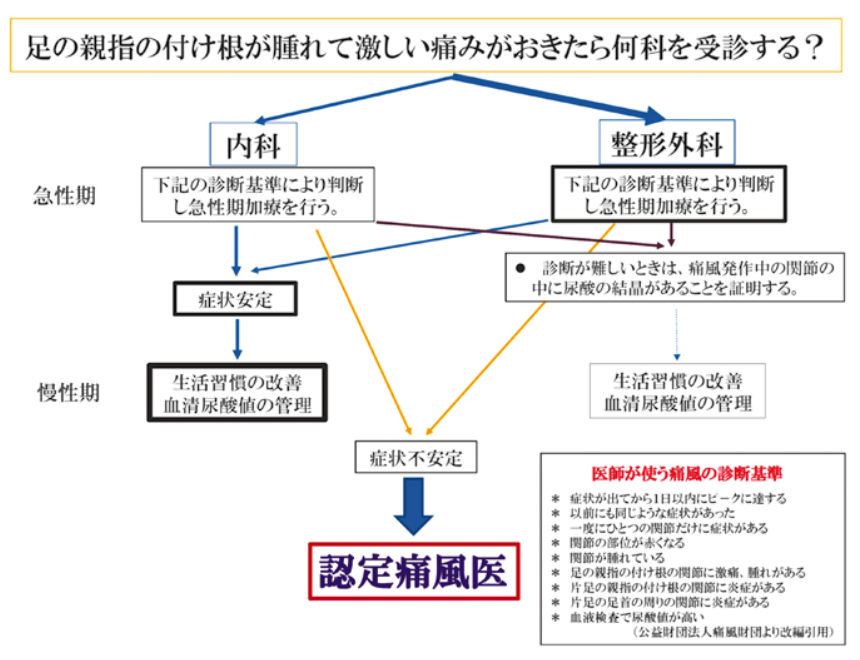

九州大学大学院医学研究院病態機能内科学

Toshio Ohtsubo 